\title{
The 'Curiouser and Curiouser' Legal Nature of Non-UN Sanctions: The Case of the US Sanctions against Russia
}

\author{
Alexandra Hofer ${ }^{1}$
}

\begin{abstract}
This article presents the legal conundrums arising from non-UN sanctions adopted by States as a means to enforce international law. Though the international legal system has developed various categories of self-help measures - from forcible acts of self-defence to non-forcible acts of retorsion or countermeasures -, applying these labels to State practice can be challenging. These complexities are perceptible in the US sanctions adopted against Russia for its alleged role in the Ukrainian crisis. Assessing the legality of the US sanctions leads to questions regarding the nature of Russia's actions in Ukraine, the purpose of the sanctions, who is targeted and why, the US' standing to respond to Russia's policies in Ukraine, etc. This article provides tentative answers but ultimately points to the grey areas governing non-forcible measures It follows that, despite appearances, the legal framework governing non-UN sanctions is messy in practice and leads to more open-ended questions than reassuring answers. The difficulty in applying seemingly clearcut legal rules to unilateral sanctions is perhaps due to the fact that States principally conceive of sanctions as policy tools and do not necessarily adopt unilateral acts to enforce legal obligations. Consequently, if international law wants to have an impact on State practice and provide for effective enforcement it is necessary to bridge the gap between legal theory and political practice.
\end{abstract}

\section{The Non-UN Sanctions Riddle Under International Law}

\section{"What's the answer?" "I haven't the slightest idea," said the Hatter. ${ }^{2}$}

Non-UN sanctions, also known as unilateral sanctions or non-forcible unilateral coercive measures, are a common feature in international relations. They are generally considered to be measures of self-help available to States, or international organizations, ${ }^{3}$ wishing to respond to transgressions of international law. These measures can encompass trade sanctions such as embargoes or limitations on exports and imports, financial sanctions, or asset freezes and travel bans (which have been dubbed 'smart' or 'targeted' sanctions).

Because of their diverse nature, a sanction's status within the international legal framework is to be established on a case-by-case basis. In general, whether or not a sanction

$1 \mathrm{PhD}$ candidate, Ghent University, Ghent Rolin-Jaequemyns International Law Institute (GRILI) (alexandra.hofer@ugent.be). This article is based on a paper that was presented during the ESIL symposium 'Legality and Legitimacy of non-UN sanctions' held on 5 May 2017 in Prague, Czech Republic. The author wishes to thank the participants of the symposium, Tom Ruys, Frédéric Dopagne, and the anonymous peerreviewers for their precise and helpful comments on previous versions. All errors remain the author's own. Unless otherwise indicated, the links were last accessed on 31 October 2017.

${ }^{2}$ Lewis Carroll, Alice's Adventures in Wonderland and Through the Looking Glass (Penguin 2000) 71.

${ }^{3}$ Unilateral sanctions can be adopted by international organizations against non-Member States on the basis of its constitutive act. For instance, the European Union (EU) frequently adopts restrictive measures against nonEU members on the basis of the Treaty on EU and the Treaty on the Functioning of the EU. They should be distinguished from multilateral sanctions, which are adopted by an international organization against a Member State, common examples are the United Nations (UN) Security Council sanctions adopted under Chapter VII of the UN Charter. 
is lawful depends on its consistency with the legal obligations the sending entity ${ }^{4}$ owes the target. Sanctions therefore either qualify as retorsions - defined as unfriendly yet lawful acts 5 - or as internationally wrongful acts. In the latter case, the illegality of the coercive measure could be excluded if they constitute lawful countermeasures. Somewhat reluctantly, ${ }^{6}$ countermeasures were codified by the International Law Commission (ILC) in its Articles on the Responsibility of States for an Internationally Wrongful Act (ARSIWA). ${ }^{7}$ As a circumstance precluding wrongfulness, countermeasures constitute a wrongful act adopted in response to a prior unlawful act the target, the responsible State, committed against the sender, the injured State. Inasmuch as the latter is reacting to a violation committed by the former, the wrongfulness of their act is precluded. ${ }^{8}$ These measures are adopted as a means to pressure the responsible State into complying with its obligations of cessation and reparation. ${ }^{9}$ Since the drafting of the ARSIWA, there has been some discussion on whether non-directly injured States ${ }^{10}$ can adopt countermeasures, and therefore if so-called 'third-party countermeasures' $^{11}$ are lawful under customary international law. The latter consist of countermeasures adopted by States other than an injured State in response to a breach of an obligation owed to a group of States for the protection of a collective interest (obligations erga omnes partes) or of an obligation owed to the international community as a whole (obligations erga omnes). ${ }^{12}$ The ILC circumvented the issue by including third-party

\footnotetext{
${ }^{4}$ The term 'sending entity' is commonly used to refer to the State or international organization that has adopted the sanction.

5 Thomas Giegerich, 'Retorsion' in Rüdiger Wolfrum (ed.) Max Planck Encyclopedia of Public International Law vol. VIII (OUP 2012) 976.

${ }^{6}$ To quote one of the ILC members, Mr Pellet, 'countermeasures might be an evil, but they were a necessary evil and in any case they were a fact of life. It was therefore necessary to accept them with a good grace, as long as international society remained essentially decentralized' in Yearbook of the International Law Commission vol. I (2000) UN Doc A/CN.4/SER.A/2000, 272, para. 52. For more see discussions between ILC members in ibid, Meetings 2646 to 2649. See also David Bederman, 'Counterintuiting Countermeasures' (2002) 96:4 AJIL 817, 817: 'The topic of countermeasures [...] proved [...] to be one of the lightning rods of criticism and controversy for the articles.'

7 Articles on the Responsibility of States for an Internationally Wrongful Act Article 22, the ARSIWA are available in Annex to UNGA Resolution 56/83 'Responsibility of States for internationally wrongful acts' (12 December 2001) UN Doc A/RES/56/83.

${ }^{8}$ Definition provided by the International Law Institute: 'Coercive measures derogatory from ordinary rules of international law, adopted by a State after another State has taken unlawful acts to its prejudice, and having the aim of imposing to the latter State, through a damage, the respect for the law' in Resolution on the regime of reprisals in peacetime (1934), Article 1. Quoted in Robert Kolb, The International Law of State Responsibility, an Introduction (Edward Elgar 2017) 175. See also Denis Alland, 'The Definition of Countermeasures' in James Crawford, Alain Pellet, Simon Olleson (eds) The Law of International Responsibility (OUP 2010) 1127, 1135: 'countermeasures are pacific unilateral reactions which are intrinsically unlawful, which are adopted by one or more States against another State, when the former consider that the latter has committed an internationally wrongful act which could justify such a reaction'; Natalino Ronzitti, 'Sanctions as instruments of coercive diplomacy: an international law perspective' in Natalino Ronzitti (ed.) Coercive diplomacy, sanctions and international law (Brill L Nijhoff 2016) 1, 11-13.

${ }^{9}$ These are the consequences of international responsibility, codified in ARSIWA (n 7) Part II, and notably Articles 29 and 30.

${ }^{10}$ Translation of the phrase 'Etats non directement lésés' in Linos-Alexandre Sicilianos, 'La Codification Des Contre-Mesures par la Commission du Droit International' (2005) Revue Belge de Droit International 447, 472473. Another term is 'indirectly injured states', Sicilianos Linos-Alexandre, 'Countermeasures in Response to Grave Violations of Obligations Owed to the International Community' in James Crawford et al. The Law of International Responsibility (OUP 2010) 1138.

${ }^{11}$ Also known as 'solidarity measures' or 'collective countermeasures'.

${ }^{12}$ ARSIWA (n 7) Articles 48(1) and 54.
} 
countermeasures in the form of a savings clause. ${ }^{13}$ According to some, however, the ILC was too cautious as practice indicates that States have accepted such measures as law. ${ }^{14}$

Despite the ILC's draft articles on countermeasures, the enforcement of international law through non-forcible measures remains an undeveloped area of international law. ${ }^{15}$ Even today 'it remains plagued by a variety of delicate controversies and grey areas' ${ }^{16}$ At the time ARSIWA was drafted, the countermeasure framework devised by the ILC was closer to the progressive development of international law than its codification. ${ }^{17}$ Although the articles on countermeasures are treated as authoritative today, ${ }^{18}$ determining whether a sanction actually constitutes a lawful countermeasure is not a straightforward exercise. Question marks arise at the beginning. Often the fact that the target is responsible for an internationally wrongful act will be disputed. ${ }^{19}$ Further it is generally unclear if the sanctioning state's response violates an obligation it owes to the responsible state. In order to constitute a countermeasure the purpose of the sanction needs to be coercive, in the sense that the sending state aims to induce the responsible state to cease its internationally wrongful act. However, as a policy tool, sanctions can be taken as punishment, as a means to signal disapproval, or in order to constrain the target's behaviour. ${ }^{20}$ Moreover, since the adoption of the ARSIWA's final text, States have transitioned from adopting comprehensive to 'targeted', or 'smart', sanctions. ${ }^{21}$ Targeted sanctions take the shape of measures directed against individuals and private entities, or restrictions against a sector of the State's economy. ${ }^{22}$ Targeted sanctions are increasingly adopted against non-State-actors. Their focus is on the individual, the group or entity believed to be responsible for, or to have supported, the actions or the behaviour that contributed to the policy the sanctioning State(s) or international organization(s) believe(s) to be vexing. It is questionable whether targeted sanctions fit within the scope of State responsibility and therefore whether they could be justified as countermeasures when wrongful. Against this backdrop, the aim of the present article is to consider the questions arising from recent State practice regarding non-UN sanctions by focusing on a specific case-study: the sanctions

${ }^{13}$ Ibid, Article 54.

14 Martin Dawidowicz, Third-Party Countermeasures in International Law (OUP 2017); Elena Katselli Proukaki, The Problem of Enforcement in International Law (Routledge 2010); Christian Tams, Enforcing Obligations Erga Omnes in International law (CUP 2005).

${ }^{15}$ Nigel D White and Ademola Abbas, 'Countermeasures and Sanctions' in Malcolm Evans, International Law (OUP 2010) 531.

${ }^{16}$ Tom Ruys, 'Sanctions, Retorsions and Countermeasures: Concepts and International Legal Framework' in Larissa van den Herik (ed), Research Handbook on U.N. Sanctions and International Law (Edward Elgar Publishing 2017) 19, 23-24.

${ }^{17}$ White and Abbas (n 15) 534.

18 See, i.e., Corn Products International v Mexico, Decision on Responsibility, ICSID Case No. ARB(AF)/04/01 (15 January 2008) paras 145-149.

${ }^{19}$ ILC, 'Draft articles on Responsibility of States for Internationally Wrongful Acts, with commentaries' in Yearbook of the International Law Commission vol. II, part II (2001) 130, para. 3.

20 The list provided here is not exhaustive. See further Kim Richard Nossal, 'International Sanctions as International Punishment' (1989) International Organization 301; David Baldwin, 'The sanctions debate and the logic of choice' (2000) 24(3) International Security 80; Francesco Giumelli 'From effective to useful sanctions: lessons learned from the experience of the European Union' in Ronzitti (n 8) 252.

${ }^{21}$ Comprehensive sanctions were discredited following the severe humanitarian crisis that resulted from the sanctions program against Iraq. Nigel D White, 'Sanctions Against Non-State Actors' in Ronzitti (n 8). See also 'Introduction' in Thomas J Biersteker, Sue E. Eckert and Marcos Tourinho (eds) Targeted Sanctions, the impacts and effectiveness of United Nations action (CUP 2016). It should be noted that the transition doesn't mean that targeted sanctions regimes do not have the same negative impact as comprehensive sanctions.

22 Throughout the article, the former will be referred to as 'targeted sanctions' and the latter as 'sectoral sanctions'. 
adopted by the United States of America (US) against the Russian Federation in the context of the Ukrainian crisis. As will be explained below, the first US sanctions were implemented in March 2014 and additional measures were taken as the crisis intensified. In order for the sanctions to be lifted, Russia is required to comply with the Minsk Agreements and cease providing assistance to pro-Russian rebels in the Luhansk and Donetsk regions. ${ }^{23}$ Russia has consistently protested that the measures against it are contrary to international law - including the UN Charter and WTO law ${ }^{24}$ - and has responded to the coercive measures in a variety of manners. In addition to adopting an embargo on agricultural goods from the sending States, ${ }^{25}$ it suspended a series of bilateral nuclear energy agreements between itself and the US in early October 2016, which included the agreement on 'Cooperation in Nuclear and Energy-Related Scientific Research and Development' adopted in 2013 (hereafter the '2013 Cooperation Agreement'). ${ }^{26}$ Russia justified the suspension as a countermeasure in response to the US sanctions, ${ }^{27}$ implying not only that it viewed its own action as unlawful but also that it believed the American measures against it are wrongful. The legality of Russia's suspension (or the preclusion of the wrongfulness of that act) would depend - in part ${ }^{28}$ - on the legality of the American sanctions that Russia is objecting to. It follows that in order to determine whether or not the suspension constitutes a valid countermeasure, it is necessary to define the legal nature of the 'anti-Russian' sanctions (section 3). First, however, background information on the sanctions adopted by the US against Russia for its alleged role in the Ukrainian conflict (section 2) is in order.

\section{The US Sanctions against Russia in the context of the Ukrainian Crisis}

\footnotetext{
23 'Ukraine ceasefire: New Minsk agreement key points' $B B C \quad(12$ February 2015) <http://www.bbc.com/news/world-europe-31436513>

${ }^{24}$ Comments by Vladimir Putin in 'Interview to American TV channel CBS and PBS' (29 September 2015) < http://en.kremlin.ru/events/president/news/50380\#sel=206:5:32j,206:28:X3j;206:29:W2v,206:53:urx>: 'the sanctions, as I said, are illegal actions, destroying the principles of the international global economy, the principles of the WTO and the UN. The sanctions may be imposed only by the decision of the UN Security Council. A unilateral imposition of sanctions is a violation of international law'; 'Comment by the Russian Ministry of Foreign Affairs regarding further anti-Russian sanctions agreed by the European Union' (30 July 2014) <http://www.mid.ru/en/foreign_policy/news/-/asset_publisher/cKNonkJE02Bw/content/id/676183>; 'Comment by the Russian Ministry of Foreign Affairs regarding the continuing anti-Russian sanctions of the United States' (30 July 2014) <http://www.mid.ru/en/foreign_policy/news//asset_publisher/cKNonkJE02Bw/content/id/676167>; 'Russia's Putin says sanctions violate principles of WTO' Reuters (19 September 2014) <http://www.reuters.com/article/us-ukraine-crisis-putin/russias-putin-sayssanctions-violate-principles-of-wto-idUSKBN0HD17V20140919>

25 'Executive Order on special economic measures to protect Russia's security' (6 August 2014) $<$ http://en.kremlin.ru/acts/news/46404>

${ }^{26}$ The full text of the 2013 Cooperation Agreement is available online here: < fissilematerials.org/library/u-sdepartment-of-energy-agreement-with-rosatom.pdf>.

27 'Suspending the Russian-US Agreement on Cooperation in Nuclear- and Energy-Related Scientific Research and Development' (5 October 2016) < http://government.ru/en/docs/24766/>, hereafter 'Decision to suspend the 2013 Cooperation Agreement'.

${ }^{28}$ A valid countermeasure must respect a series of criteria codified by the ILC in ARSIWA (n 7) Articles 49 to 53: (i) they can only be taken by the injured State against the State responsible for the internationally wrongful act; (ii) they are limited in scope, their aim being to induce compliance with the obligations of cessation and reparation; they should therefore be (ii) temporary and, when possible, (iii) reversible; (iv) they 'must be commensurate with the injury suffered'; (v) they must not adversely affect peremptory norms; etc. This piece focuses on the first criteria, the commission of an internationally wrongful act.
} 
At the time the 2013 Cooperation Agreement was suspended, the US sanctions against Russia comprised the measures stemming from the Magnitsky Act ${ }^{29}$ and those adopted in 2014 in relation to the Ukrainian crisis. ${ }^{30}$ The American Congress justified the former as a response to gross human rights violations, whereas the latter are explained as, inter alia, a reaction to the violation of Ukraine's territorial and sovereign integrity. In summer 2017, the American Congress expanded the sanctions against Russia by adopting the Countering America's Adversaries Through Sanctions Act. ${ }^{31}$ Though the Kremlin has objected to the Magnitsky Act, including with regard to the suspension of another nuclear-related agreement, ${ }^{32}$ and the Countering America's Adversaries Through Sanctions Act, ${ }^{33}$ this article will be limited to the measures adopted in relation to the Ukrainian crisis. These measures form a complex web of legislation adopted by Congress and Presidential Executive Orders (E.O.). ${ }^{34}$ However the primary sanction sources are Executive Orders 13660, 13661, 13662 and 13685, which will be the focus of the analysis in section 3 .

The Ukrainian crisis was triggered by former President Viktor Yanukovych's decision to drop out of an agreement with the European Union in favour of closer ties with Russia in

29 H.R. 4405 Magnitsky Rule of Law Accountability Act of 2012, $112^{\text {th }}$ Congress $(2011-2012)<$ https://www.congress.gov/bill/112th-congress/house-bill/4405/text>. Sergei Magnitsky was a Russian lawyer who accused the Russian government of fraud and corruption. He died after suffering from grave physical assaults in prison and receiving inadequate medical care. The Magnitsky Act aims to hold those suspected of being responsible for his death accountable by subjecting them to travel bans and asset freezes. It also targets individuals for alleged acts of corruption. The Senate expanded the Magnitsky Legislation in 2016, allowing the US to impose targeted sanctions against individuals anywhere in the world for breaches of human rights and acts of corruption (S.284 - Global Magnitsky Human Rights Accountability Act, 114 ${ }^{\text {th }}$ Congress (2015-2016). The US has inspired other countries, in particular Canada (Justice for Victims of Corrupt Foreign Officials Regulations, SOR/2017-233) and the United Kingdom (The Criminal Finances Act 2017 (Commencement No. 4) Regulations 2018).

30 These measures include Executive Order 13660 of 6 March $2014<$ https://www.treasury.gov/resourcecenter/sanctions/Programs/Documents/ukraine_eo.pdf>; Executive Order 13661 of 16 March $2014<$ https://www.treasury.gov/resource-center/sanctions/Programs/Documents/ukraine_eo2.pdf >; Executive Order 13662 of $20 \quad$ March $2014 \quad$ https://www.treasury.gov/resourcecenter/sanctions/Programs/Documents/ukraine_eo3.pdf >; and Executive Order 13685 of 19 December $2014<$ https://www.treasury.gov/resource-center/sanctions/Programs/Documents/ukraine_eo4.pdf $>$; as well as the directives expanding the scope of Executive Order 13662, available here < https://www.treasury.gov/resourcecenter/sanctions/Programs/pages/ukraine.aspx>. In addition, the following acts were adopted by Congress: Support for the Sovereignty, Integrity, Democracy, and Economic Stability of Ukraine Act of $2014<$ https://www.congress.gov/113/plaws/pub195/PLAW-113pub195.pdf>; Ukraine Freedom Support Act of $2014<$ https://www.congress.gov/113/plaws/publ272/PLAW-113publ272.pdf >; the United States International Programming to Ukraine and Neighbouring Regions Bill < https://www.congress.gov/bill/113thcongress/senate-bill/2183>.

${ }^{31}$ H.R.3364 Countering America's Adversaries Through Sanctions Act, 115th Congress (2017-2018), available here <https://www.congress.gov/bill/115th-congress/house-bill/3364/text> The Act became public law on 2 August 2017. It also targets North Korea and Iran.

32 'Draft law suspending the Russia-US Plutonium Management and Disposition Agreement submitted to the State Duma' (3 October 2016) <http://en.kremlin.ru/acts/news/53009>

33 'Russia Seizes 2 U.S. Properties and Orders Embassy to Cut Staff' NY Times (30 July 2017 <https://www.nytimes.com/2017/07/28/world/europe/us-russia-sanctions.html> See also President Putin's response to questions in 'Joint news conference with President of Finland Sauli Niinisto' (27 July 2017) $<$ http://en.kremlin.ru/events/president/news/55175>.

${ }^{34}$ See legislation (n 30). An overview of the US sanctions can be found here: Erica Moret, Francesco Giumelli and Dawid Jarosz 'Sanctions on Russia: Impacts and Economics costs on the United States' Programme for the Study of International Governance, Graduate Institute Geneva (20 March 2017) < graduateinstitute.ch/files/live/sites/iheid/files/sites/internationalgovernance/shared/Russian-Sanctions-Report.pdf $>$, including a timeline at 8 . 
November 2013. ${ }^{35}$ This initially provoked minor protests but the situation steadily escalated as the clashes between protesters and the riot police became increasingly violent. Ultimately, the protests led to the flight of President Yanukovych, making way for the opposition to take power during the final week of February 2014. It is around this time that pro-Russian forces were reported to have seized control of Crimea and eastern parts of Ukraine. Armed groups took control of government buildings in Crimea on 27 February 2014 and Crimea's Supreme Council announced a referendum to be held on Crimea's reunification with Russia on 16 March. Meanwhile, heavily armed individuals with military fatigues but without insignia had been sighted along the peninsula; they were suspected to be Russian troops. ${ }^{36}$ Furthermore, on 1 March, following the Prime Minister of Crimea's request for military assistance and an invitation to intervene by (former) President Yanukovych, President Putin obtained permission from the Russian Duma to deploy troops in Crimea.

The Ukrainian crisis was closely monitored by the US. ${ }^{37}$ On 28 February, President Obama expressed 'deep concern' over the reports of Russia's movements in Ukraine; ${ }^{38}$ stating that

any violation of Ukraine's sovereignty and territorial integrity would be deeply destabilizing [...] It would represent a profound interference in matters that must be determined by the Ukrainian people. It would be a clear violation of Russia's commitment to respect the independence and sovereignty and borders of Ukraine, and of international laws. ${ }^{39}$

The White House also indicated they would 'stand with the international community in affirming that there will be costs for any military intervention in Ukraine.' ${ }^{40}$ Costs for its alleged behaviour in Ukraine were initially inflicted on Russia through a series of diplomatic measures coordinated between the US and the EU. This involved the cancellation of bilateral meetings and Russia's exclusion from the G8. It is within this context that the first Executive Order was adopted, E.O. 13660 of 6 March 2014. The events occurring in Crimea were described in the following manner:

actions and policies of persons including persons who have asserted governmental authority in the Crimean region without the authorization of the Government of Ukraine that undermine democratic processes and institutions in Ukraine; threaten its peace, security, stability, sovereignty, and territorial integrity; and contribute to the misappropriation of its assets [...]. ${ }^{41}$

\footnotetext{
${ }^{35}$ For the facts leading up the Crimean annexation see Tom Ruys and Nele Verlinden 'Digest of State Practice: 1 January - 30 June 2014' (2014) 1:2 Journal on the Use of Force and International Law 323, 324-340. For the facts outlined in this paragraph see ibid, 324-326.

${ }^{36}$ UNSC Verbatim Record (1 March 2014) UN Doc S/PV.7124, 2 (Deputy Secretary General). President Putin originally denied the troops were Russian but then confirmed it in April 2014, see Ruys and Verlinden (n 35) 325 , footnote 5 .

37 As evidenced by 'Responding to the Situation in Ukraine' <https://obamawhitehouse.archives.gov/blog/2014/02/20/responding-situation-ukraine $>$.

38 'Statement by the President on Ukraine' (28 February 2014) < https://obamawhitehouse.archives.gov/thepress-office/2014/02/28/statement-president-ukraine>.

${ }^{39}$ Ibid.

40 Ibid.

${ }^{41}$ E.O. 13660 (n 30) at 13493.
} 
Such policies were described as 'an unusual and extraordinary threat to the national security and foreign policy of the United States'. ${ }^{42}$ The US government implemented asset freezes and travel bans against persons, meaning individuals and entities, believed to have taken part in 'actions or policies that undermine democratic processes or institutions in Ukraine'; 'actions or policies that threaten the peace, security, stability, sovereignty, or territorial integrity of Ukraine'; the 'misappropriation of state assets of Ukraine or of an economically significant entity in Ukraine'; or to have 'asserted governmental authority in the Crimean region without the authorization of the Government of Ukraine'. ${ }^{43}$ These measures were adopted before the referendum on Crimea's status and therefore before its annexation by the Russia State. The text of the executive order does not explicitly describe the sanctions as a response to the (at the time alleged) deployment of Russian troops. It follows that the sanctions do not appear to target Russia for wrongful behaviour in Ukraine ${ }^{44}$ but only individuals and entities, the majority of which are of Ukrainian nationality although Russian citizens and corporations based in Russia are also listed. ${ }^{45}$ The absence of any reference to Russia in E.O. 13660 is striking if we consider that it was framed as part of the measures taken 'in response to Russia's ongoing violation of Ukraine's sovereignty and territorial integrity'. ${ }^{46}$ They were described by President Obama as a means to impose costs on Russia and 'those responsible' for the situation in Crimea. ${ }^{47}$

Following the referendum in Crimea and the region's annexation by Russia, President Obama signed two additional executive orders on 16 and 20 March. $^{48}$ The first measure, E.O. 13661, expanded the scope of the asset freeze and travel bans to officials of the Government of Russia as well as individuals and entities that operate 'in the arms or related material sector in the Russian Federation'. Individuals with significant resources and Bank Rossiya were listed for providing support to the Russian leadership. The second measure, E.O. 13662, listed sectors of the Russian economy, 'such as financial services, energy, metals and mining, engineering, and defence and related material'. ${ }^{49}$ Citing 'the actions and policies of the Government of the Russian Federation with respect to Ukraine', both executive orders explicitly single out the Russian government for its unlawful policies in Crimea, thereby invoking Russia's State responsibility. Indeed, the motivation for E.O. 13661 reads:

\footnotetext{
42 Ibid.

${ }^{43}$ Ibid, sections 1(a)(i) and 1(a)(ii).

${ }^{44}$ They could nevertheless be understood as a signal to Russia that more serious measures would be taken if necessary; see 'President Obama Discusses Efforts to Address the Ongoing Crisis in Ukraine' (6 March 2014) < https://obamawhitehouse.archives.gov/blog/2014/03/06/president-obama-discusses-efforts-address-ongoingcrisis-ukraine>: 'if this violation of international law continues the resolve of the United States and our allies and the international community will remain firm. Meanwhile we have taken steps to reaffirm our commitment to the security and democracy of our allies in eastern Europe'. Although this threat was ineffective, see Erica Moret et al., 'The new deterrent? International sanctions against Russia over the Ukraine crisis: Impacts, costs and further action' Programme for the Study of International Governance, Graduate Institute Geneva (12 October 2016) <graduateinstitute.ch/files/live/sites/iheid/files/sites/internationalgovernance/shared/The\%20New\%20Deterrent \%20International\%20Sanctions\%20Against \%20Russia\%20Over\%20the\%20Ukraine\%20Crisis\%20-

$\% 20$ Impacts $\% 2 \mathrm{c} \% 20 \mathrm{Costs} \% 20$ and\%20Further\%20Action.pdf $>$ at 10, referring to the 'Threat stage (23 Feb.- 14 March) and Annex 4 at 36.

45 This was reviewed by the present author through OFAC's sanctions list search < https://sanctionssearch.ofac.treas.gov/> on 20 September 2017.

46 'Statement by the Press Secretary on Ukraine' (6 March 2014) <https://obamawhitehouse.archives.gov/thepress-office/2014/03/06/statement-press-secretary-ukraine>.

47 'President Obama Discusses Efforts to Address the Ongoing Crisis in Ukraine' (n 44).

48 'Statement by the President on Ukraine' (17 March 2014) <https://obamawhitehouse.archives.gov/the-pressoffice/2014/03/17/statement-president-ukraine>; 'President Obama speaks on Ukraine' (20 March 2014) $<$ https://www.youtube.com/watch?v=P27AaOqbDa4\&feature=youtu.be>.

${ }^{49}$ E.O. 13662 (n 30).
} 
the actions and policies of the Government of the Russian Federation with respect to Ukraine - including the recent deployment of Russian Federation military forces in the Crimea region of Ukraine - undermine democratic processes and institutions in Ukraine; threaten its peace, security, stability, sovereignty, and territorial integrity; and contribute to the misappropriation of its assets, and thereby constitute an unusual and extraordinary threat to the national security and foreign policy of the United States. ${ }^{50}$

The language of Executive Order 13662 is similar but refers to the 'purported annexation of Crimea and its use of force in Ukraine' rather than to the 'deployment of Russian military forces'. ${ }^{51}$ These sanctions were extended through the adoption of directives amending Executive Order 13662 in July and September 2014.

To cite the US Department of State, through Executive Orders 13660, 13661 and 13662 the US has 'steadily increased the diplomatic and financial costs of Russia's aggressive actions towards Ukraine'. ${ }^{52}$ Following the downing of the MH17 in July 2014, the sanctions were expanded as additional individuals, entities, and sectors were listed. ${ }^{53} \mathrm{In}$ response to the sanctions against it, Russia adopted counter-sanctions consisting of travel bans in March 2014 and an embargo on agricultural products in August the same year. ${ }^{54}$

In addition, on 19 December, President Obama signed E.O. 13685, entitled 'Blocking Property of Certain Persons and Prohibiting Certain Transactions with Respect to the Crimea Region of Ukraine'. ${ }^{55}$ This measure implemented supplementary 'steps to address the Russian occupation of the Crimea region of Ukraine'. The order prohibits investment and trade with the Crimean region and imposes an asset freeze and travel ban on individuals and entities operating in Crimea.

Since their adoption, the US has reiterated that the sanctions are a reaction to the blatant violation of Ukraine's territorial and sovereign integrity. ${ }^{56}$ The measures are consistent with the American administration's view that it may legitimately use its economic power to

\footnotetext{
${ }^{50}$ E.O. 13661 (n 30).
}

${ }^{51}$ E.O. 13662 (n 30).

52 US Department of State, Archived content 'Ukraine and Russia sanctions' <https://20092017.state.gov/e/eb/tfs/spi/ukrainerussia/index.htm> Accessed 31 March 2017.

${ }^{53}$ US Department of the Treasury, 'Treasury Sanctions on Entities Within the Financial Services and Energy Sectors of Russia, Against Arms or Related Materiel Entities, and those Undermining Ukraine's Sovereignty' (16 July 2014) < https://www.treasury.gov/press-center/press-releases/Pages/j12572.aspx > For further expansions of the sectoral sanctions see: OFAC, Ukraine/Russia related sanctions program (updated 16 June 2016) at $5<$ https://www.treasury.gov/resource-center/sanctions/Programs/Documents/ukraine.pdf>

${ }^{54}$ Ministry of Foreign Affairs, 'Statement by the Russian Ministry of Foreign Affairs on retaliatory sanctions with regard to several officials and members of the US Congress' $(20$ March 2014) < http://www.mid.ru/en/foreign_policy/news/-/asset_publisher/cKNonkJE02Bw/content/id/69698> ; 'Executive order on applying certain special economic measures to ensure the security of the Russian Federation' (6 August 2014) <http://en.kremlin.ru/events/president/news/46404>. These measures were adopted against the EU, the US and States that had aligned themselves with their policies.

55 E.O. 13685 of December 19, 2014. Note that the previous day H.R. 5859 Ukraine Freedom Support Act became law < https://www.congress.gov/bill/113th-congress/house-bill/5859/actions $>$.

${ }^{56}$ See, e.g., UNSC Verbatim Record (March 19 2014) UN Doc S/PV.7144, 10 (USA): 'Two days ago, President Obama and other world leaders put in place sanctions in response to Russia's blatant disregard for global opinion and the legal rights of Ukraine'; Remarks by President Obama to the UNGA (Sept 28 2015) 5 <https://gadebate.un.org/sites/default/files/gastatements/70/70_US_EN.pdf> Accessed 31 March 2017, explaining that the aim of the sanctions against Russia is to protest against the violation of Ukraine's territory and sovereignty. 
achieve its foreign policy and security goals and to defend essential norms of the international community. ${ }^{57}$ In early 2017, it was unclear if the Trump administration would maintain the coercive measures against Russia. During his final press conference in January 2017, former President Obama recalled that:

The reason we imposed the sanctions [...] was because the independence and sovereignty of a country, Ukraine, had been encroached upon by force, by Russia. That wasn't our judgment, that was the judgment of the entire international community. [...] What I've said to the Russians, is as soon as you stop doing that, the sanctions will be removed. And I think it would probably best serve, not only American interests, but also the interests of preserving international norms $[\ldots] .^{58}$

Before leaving office, Barack Obama extended the national emergency with respect to Ukraine until 2018. ${ }^{59}$ Congress has since adopted the Countering America's Adversaries Through Sanctions Act, because it sensed, inter alia, that the President 'should continue to uphold and seek unity with European and other key partners on sanctions implemented against the Russian Federation [... $]^{60}$ and thereby codified previously adopted executive orders. ${ }^{61}$ President Trump's capacity to unilaterally lift the US sanctions was restricted by the Act. $^{62}$

It follows that the Executive Orders adopted between 6 March and 19 December 2014 are a response to Russia's role in the Ukrainian crisis. In order to assess whether these measures could constitute internationally wrongful acts that would justify Russia's resort to countermeasures, it is necessary to determine their legal nature and whether they qualify as retorsions, internationally wrongful acts or lawful (third-party) countermeasures.

\section{Going Down the Rabbit Hole: the Legal Nature of the US Executive Orders against Russia}

In the proceeding analysis, we examine the legal nature of the Executive Orders by answering the following questions: (i) who is targeted by the Executive Order? (ii) What are the reasons given for adopting the act? (iii) Could the sanctions constitute a violation of obligations the US owes the targeted entity? (iv) If so, could Russia invoke US' responsibility and (v) could

\footnotetext{
${ }^{57}$ See, e.g., UNGA Third Committee Verbatim Record (20 November 2015) UN Doc A/C.3/70/SR.52, para. 32 and OFAC, 'Remarks of Secretary Lew on the Evolution of Sanctions and Lessons for the Future...' <https://www.treasury.gov/press-center/press-releases/Pages/j10398.aspx>: 'The power of our sanctions is inextricably linked to our leadership role in the world. Sanctions were forged in the context of our position as the world's largest economy and the predominant role that the U.S. financial system plays in global commerce.' both discussed in Alexandra Hofer, 'The Developed/Developing Divide on Unilateral Coercive Measures: Legitimate Enforcement or Illegitimate Intervention?’ (2017) 16:2 Chinese JIL, paras 24 and 41.

58 'Obama's Last News Conference: Full Transcript and Video', NY Times (18 January 2017) <https://www.nytimes.com/2017/01/18/us/politics/obama-final-press-conference.html?_r=0> Accessed 02 February 2017.

59 'Notice - Continuation of National Emergency with Respect to Ukraine' (13 January 2017) < https://obamawhitehouse.archives.gov/the-press-office/2017/01/13/notice-continuation-national-emergencyrespect-ukraine>.

${ }^{60}$ Countering America's Adversaries Through Sanctions Act (n 31) section 212(1). See also section 252.

${ }^{61}$ Ibid, section 222.

${ }^{62}$ Ibid, section 230
} 
the US respond by invoking the (third-party) countermeasure argument? The answers to these questions help determine which legal category can be applied to the US sanctions.

At the outset, it should be noted that it is generally difficult to determine whether a sanction violates an international obligation the sending State owes to the target State. Indeed, the identification of an unlawful sanction is a complicated exercise that 'is very often open to question'. ${ }^{63}$ For this reason, it is not the purpose of this section to reach a definitive conclusion on the legal nature of the US sanctions. Instead, the intention is to provide an overview of the various questions that arise from the unilateral coercive measures and to which there are no straightforward answers.

\section{A. Executive Order 13660 of 6 March 2014}

The sanctions adopted 6 March constitute targeted sanctions in the form of asset freezes and travel bans against non-State actors, mainly Ukrainian but also Russian individuals and entities, without invoking Russia's State responsibility for an internationally wrongful act. ${ }^{64}$ The persons targeted by Executive Order 13660 are believed to be responsible for actions that threaten Ukraine's territorial integrity and sovereignty, that undermine its democratic policies and institutions and who are believed to have misappropriated Ukrainian State funds. ${ }^{65}$

Targeted sanctions are practically unregulated by international law ${ }^{66}$ with the exception, indubitably, of the rights the sender(s) owe(s) to the listed persons. In general, these consist of (i) human rights ${ }^{67}$ or (ii) obligations stemming from investment treaties, which we address in turn.

To borrow Happold's words, targeted sanctions - whether asset freezes or travel bans cannot 'be said, in general, to infringe substantive human rights'. ${ }^{68}$ Although they can potentially erode an individual's right to the freedom of movement, right to property or even the right to private life, these rights are not absolute and can be transgressed if the restriction is proportional. ${ }^{69}$ Concerning travel bans restricting freedom of movement, whereas there is a right to leave a country there is no right to enter a country, lest it is the individual's country of residence. ${ }^{70}$ Cases where violations are found to be disproportionate are generally the exception. Consequently, Happold finds that in most scenarios such restrictions would be proportionate if the interest at stake is, for instance, the maintenance or restoration of international peace and security. In the case of US sanctions, they are generally adopted under the rubric of national security and seek to respond to a "national emergency'. ${ }^{71}$ When the

63 Carlo Focarelli, 'International law and third-party countermeasures in the age of global instant communication’ (2016) 29 QIL 17, 18.

${ }^{64}$ See text at (n 41), referring to 'persons'.

${ }^{65}$ See also 'Statement by the Press Secretary on Ukraine' (6 March 2014) (n 46).

${ }^{66}$ White, 'Sanctions against non-State Actors' (n 21) 158-160.

67 Matthew Happold, 'Targeted Sanctions and Human Rights' in Matthew Happold and Paul Eden (eds), Economic sanctions and international law (Hart Publishing 2016); Monica Lugato 'Sanctions and individual rights' in Ronzitti (n 8) 189: 'individuals rights are a limit both to the decision and to the implementation of targeted sanctions.'

${ }^{68}$ Happold (n 67) 92, 96. See also Charlotte Beaucillon, Les Mesures Restrictives de l'Union Européenne (Bruylant 2014) 398 and 400-401.

${ }^{69}$ Happold (n 67) 95; Lugato (n 67) 183: 'limitations to the enjoyment of human rights are legally admissible, within the perimeter defined by human rights law'

${ }^{70}$ Michael Bothe, 'Compatibility and Legitimacy of Sanctions Regimes' in Ronzitti (n 8) 33, at 39.

${ }^{71}$ This is consistent with 'International Emergency Economic Powers Act' (IEEPA), full text available here: < https://www.treasury.gov/resource-center/sanctions/Documents/ieepa.pdf>. 
reasons for the legal persons' listing are not sufficiently substantiated then they could constitute a violation of their rights; this is to be determined through the judicial process. It is generally at this stage that difficulties arise.

According to White, unilateral sanctions against non-State actors adopted as punishment for alleged violations of international law, or in the present case for purported violations of Ukraine's constitutional law, ${ }^{72}$ 'do not necessarily follow from any judicial determination of guilt, thereby rendering [them] automatically [violations] of due process rights'. ${ }^{73}$ In other words, individuals are punished before their guilt is ascertained. The EU's restrictive measures are frequently challenged before the European Court of Justice for their lack of legal basis and merit, as are UN sanctions. In the US, individuals or entities wishing to challenge their listings face considerable procedural obstacles. ${ }^{74}$ In the event that the targeted entities gain access to judicial review, they must face the US courts' highly 'deferential' attitude towards sanctions review. The judiciary's deference is explained by sanctions' foreign policy nature and the sensitivities surrounding national security. ${ }^{75}$ According to Fitzgerald, sanctions' 'programs are effectively devoid of the procedural and substantive due process protections that would be associated with similar actions if they were taken pursuant to civil or criminal law' ${ }^{76}$ Consequently, in terms of human rights, the salient issue appears to be the targeted sanctions' compatibility with procedural rights and the possibility of judicial review.

Turning to the second area of concern, Ruys suggests that sanctions may conflict with Article VIII(2)(a) of the IMF Agreement, or with rules stemming from the treatment of aliens and investment protection. ${ }^{77}$ Further, van Aaken writes that asset freezes imposed by individual States 'may possibly conflict with international investment law'. ${ }^{78}$ She also submits that 'the sanctions against Russia by non-injured states would likely be violating the IIAs, and the sanctioning states would need to pay damages'. ${ }^{79}$ However, at the time the sanctions were adopted there was no Bilateral Investment Treaty in force between Russia and the US ${ }^{80}$ In addition, as two commentators have noted, State practice provides little insight when breaches of contracts and agreements are caused by unilateral sanctions, 'since States are quite reluctant to bring claims against their counterparties in case of international sanctions' ${ }^{81}$ It

\footnotetext{
${ }^{72}$ US Officials frequently referred to the referendum of March 2014 as a violation of Ukraine's constitution, see i.e. 'Statement by the Press Secretary on Ukraine' (16 March 2014) <https://obamawhitehouse.archives.gov/thepress-office/2014/03/16/statement-press-secretary-ukraine>.

${ }^{73}$ White (n 20) 139.

${ }^{74}$ Peter L Fitzgerald, 'Smarter “Smart” Sanctions' (2007) 26 Penn State International Law Review 37, notably 48; Peter L. Fitzgerald, 'Drug kingpins and blacklists: Compliance issues with US economic sanctions: Part 2' (2001) 5:1 Journal of Money Laundering Control 66, 73-75; Peter L. Fitzgerald, "If Property Rights Were Treated Like Human Rights, They Could Never Get Away with This": Blacklisting and Due Process in U.S. Economic Sanctions Programs' (1999) 59 Hastings Law Journal 73, 136-138. On the procedure for challenging listings in the US see also Rachel Barnes 'United States Sanctions' in Happold and Eden (n 67).

${ }^{75}$ Barnes (n 74); see also White (n 21) 139; and Fitzgerald '"If Property Rights Were Treated like Human Rights...' (n 74) 139, 149-150

${ }^{76}$ Fitzgerald, 'Smarter "Smart” Sanctions' (n 74) 50-51. He says this about US, EU and UN sanctions.

${ }^{77}$ Ruys (n 16) 31.

${ }^{78}$ Anne van Aaken, 'International investment law and decentralized targeted sanctions: an uneasy relationship' (4 January 2016) $\mathrm{n}^{\circ} 164$ Columbia FDI Perspectives, 1 <http://ccsi.columbia.edu/files/2013/10/No-164-vanAaken-FINAL.pdf> Accessed 31 March 2017.

${ }^{79}$ van Aaken (n 78) 2.

80 Although one was signed in 1992 but it did not enter into force, see <http://investmentpolicyhub.unctad.org/IIA/CountryBits/175\#iiaInnerMenu> Accessed 31 March 2017. However, an 'Investment Incentive Agreement' was signed in 1992 and remains in force.

${ }^{81}$ Andrea Atteritano and Maria Beatrice Deli, 'An Overview of International Sanctions' Impact on Treaties and Contracts' in Ronzitti (n 8) 207, 216. Their discussion was mainly focused on justifying the suspension of a
} 
should be noted that E.O. 13660 is rather ambiguous; it states that the asset freezes 'apply except to the extent provided by statutes, or in regulations, orders, directives or licenses that may be issued pursuant to this order, and notwithstanding any contract entered into or any license or permit granted prior to the effective date of this order. ${ }^{92}$ This would seem to suggest that the measures adopted automatically trump any previous 'contract', which could encompass investment agreements, ${ }^{83}$ and could therefore amount to a breach of the targeted person's rights under such agreements. ${ }^{84}$ However, it is equally possible that if there would be a conflict between the investor's rights under a previous agreement that OFAC would allow an exception.

Summing up, violations arising from E.O. 13660 need to be determined on a case-by-case basis. If there would be an infringement, it would constitute a violation of an obligation owed to the targeted person and not the Russian State. The latter would only have standing to invoke US responsibility if it were to exercise diplomatic protection and seek to protect the rights of Russian persons. ${ }^{85}$ There are, of course, a series of criteria that would need to be fulfilled for Russia to be able to invoke diplomatic protection: (i) the person concerned needs to be of Russian nationality and (ii) the person will need to have exhausted all local and effective remedies in the US.

Assuming these conditions are met and Russia chooses to invoke US responsibility for violating its nationals' rights through the targeted sanctions, the question is whether the US could invoke the countermeasure argument to preclude the wrongfulness of the sanctions. As explained in this article's introduction, in order for the countermeasure argument to be valid certain conditions need to be respected. In this section we temporarily leave aside the issue of US standing to adopt countermeasures ${ }^{86}$ and focus on the criteria that the sanction needs to constitute a response to an internationally wrongful act attributable to a State. ${ }^{87}$

Executive Order 13660 targets persons involved in 'actions or policies that undermine democratic processes or institutions in Ukraine', 'actions or policies that threaten the peace, security, stability, sovereignty, or territorial integrity of Ukraine' and 'misappropriation of state assets of Ukraine or of an economically significant entity in Ukraine'. It also targets persons that 'have asserted governmental authority over any part or region of Ukraine without the authorization of the Government of Ukraine'. Taking into account the timeline of events in Ukraine, the US measures were adopted in reaction to non-State actors disrupting the peace in eastern Ukraine, seizing control of the Crimean region without the authority of the Ukrainian government and the announcement that a referendum on Crimea's status would occur in violation of Ukraine's constitutional law. The sanctions therefore read as a response to internal unrest that would have been caused by Ukrainian dissidents, albeit it was believed they were supported by Russia. Although these events gave rise to concern and forewarned

treaty pursuant to unilateral sanctions adopted by the EU under the VCLT (1969) and not under the law of State responsibility, 212-214.

${ }^{82}$ E.O. 13660, sec 1(b) (emphasis added).

${ }^{83}$ For a general discussion on the effect of sanctions on private contracts see Penelope Nevill, 'Sanctions and Commercial Law' in Happold and Eden (n 67) 227-251.

${ }^{84}$ See also Bothe (n 70) 41.

${ }^{85}$ Draft Articles on Diplomatic Protection, Article 1, available in Report of the International Law Commission, 58th session (1 May-9 June and 3 July-11 August 2006) UN Doc A/61/10; See also Martins Paparinskis, 'Investment Arbitration and the Law of Countermeasures' (2009) 79 BYBIL 264.

${ }^{86}$ See section 3(B)(iii).

${ }^{87}$ ARSIWA (n 7) Article 22: 'The wrongfulness of an act of a State not in conformity with an international obligation towards another State is precluded if and to the extent that the act constitutes a countermeasure taken against the latter State...' 
what was to come, the Executive Order does not cite Russia as being directly responsible for what was occurring in the peninsula. The lack of any reference to Russia stands in stark contrast to the oral justifications given by US State officials. ${ }^{88}$ The Executive Order does not directly invoke Russia's State responsibility, contrary to Executive Orders 13661 and 13662 discussed below. With one exception, the persons targeted by E.O. 13660 do not exercise governmental functions; ${ }^{89}$ they do not appear to be agents or organs of the Russian State. ${ }^{90}$ In addition to signalling support to the Ukrainian authorities, these sanctions should be understood as warning Russia that any further involvement in Ukraine could lead to more stringent measures. ${ }^{91}$ Under these circumstances the sanctions would appear to fall outside the purview of the ILC's draft articles on State responsibility since they are not confined to Stateto-State relations and are not a response to an internationally wrongful act committed by a State but rather to destabilising acts committed by Ukrainian persons. As individuals are 'structurally incapable of triggering the entitlement for the State to adopt countermeasures', 92 the US could not invoke the countermeasure argument to preclude the (potential) wrongfulness of the sanctions stemming from E.O. 13660.

It follows from the above that if the US sanctions do constitute a violation of rights owed to persons of Russian nationality, and if Russia were to exercise diplomatic responsibility, and seeing as it is highly unlikely that a circumstance precluding wrongfulness would be applicable, then Russia could conceivably adopt countermeasures against the US in order to pressure it into lifting its wrongful sanctions against its nationals.

\section{B. Executives Orders 13661 of 16 March and 13662 of 20 March}

The measures that, according to the present author, directly invoke Russia's State responsibility for the events in Ukraine are the Executives Orders adopted on 16 and 20 March 2014. Indeed, both measures were adopted following Crimea's integration into the Russian Federation and refer to the 'actions and policies of the Government of the Russian Federation with respect to Ukraine'. The coercive measures contain targeted sanctions against individuals and entities (E.O. 13661) and restrictions of economic relations between the US and Russia (E.O. 13662).

\section{(i) Executive Order 13661}

The first set of measures constitutes targeted sanctions against legal persons; they therefore fall under the above-described legal framework of E.O. 13660. Whereas the latter lists nonState actors, Executive Order 13661 targets 'official[s] of the Government of the Russian

\footnotetext{
${ }^{88}$ See UNSC Verbatim Record (1 March 2014) UN Doc S/PV.7124, 5-6 (Ms Powers, United States of America). As noted above, Russia was reported to have militarily invaded Ukraine on 28 February 2014, see above (n 36), and this is referred to in President Obama's statements on 28 February 2014 (n 38) and of 6 March 2014 (n 44), however E.O. 13660 does not cite this.

${ }^{89}$ This was verified by the author via OFAC's sanctions list search $<$ https://sanctionssearch.ofac.treas.gov/ $>$ on 20 September 2017. One exception however is Sergey Nazarov, the Deputy Minister of Economic Development of the Russian Federation. Mr Nazarov appears to have been listed on 20 June 2017, over three years after the Executive Order's adoption. See OFAC, Russia/Ukraine-related Designations and Identifications, Specially Designated Nationals List Updates (20 June 2017) < https://www.treasury.gov/resource-center/sanctions/OFACEnforcement/Pages/20170620.aspx>.

${ }^{90}$ Within the meaning of ARSIWA (n 7) Articles 4 and 5.

${ }^{91}$ See Moret et al. (n 44) at 10.

92 Paparinskis (n 85) 334.
} 
Federation', persons that 'have acted or [are] purported to [have acted] for or on behalf of, directly or indirectly', such officials. It also targets persons that 'operate in the arms or related materiel sector in the Russian Federation' and entities that are owned or controlled by 'a senior official of the Government of the Russian Federation'.

These coercive measures target Russia through individuals and entities that are believed to be responsible for or to have contributed to the contested policy. Accordingly, they comprise a response to an internationally wrongful act committed by the Russian State against Ukraine. Furthermore, the consequences of the sanctions are mixed, in the sense that any injury they cause affects both the targeted persons - causing indirect injury to Russia - and the State producing direct harm. ${ }^{93}$ This has the potential of bringing the targeted measures into the ambit of State-to-State relations and under the scope of State responsibility without Russia having to invoke diplomatic protection when the injury is considered to be direct.

If Russia were to invoke US responsibility for wrongful targeted sanctions - either directly or through diplomatic protection - could the US raise the countermeasure argument? Seeing as Ukraine is the directly injured State, under the articles on State responsibility drafted by the ILC the US would only have standing as an interested third-party under Article $48 .{ }^{94}$ This leads to the question of US standing to adopt countermeasures against Russia for unlawful acts committed against Ukraine and whether third-party countermeasures constitute 'lawful measures' as provided for under ARSIWA Article 54, which will be discussed below..$^{95}$

\section{(ii) Executive Order 13662}

The measures implemented pursuant to Executive Order 13662 consist of sectoral sanctions against entities operating in the Russian economy. They target Russia's energy, finance and defence sectors. ${ }^{96}$ These measures include an arms embargo, generally understood as an act of retorsion, ${ }^{97}$ restrictions of financial transactions with Russian companies as well as the prohibition of exporting 'goods, services, or technology in support of exploration or production for deepwater, Artic offshore, or shale projects that have the potential to produce oil in Russia or in the maritime area claimed by Russia' ${ }^{98}$ Such measures are unlawful if they violate a bilateral agreement between Russia and the US, a multilateral treaty both States are party to or an obligation under customary international law.

It has been suggested that the sanctions violate US obligations to Russia under GATT, ${ }^{9}$ which Russia joined in 2012. Russia has allegedly stated that the sanctions infringe WTO law

\footnotetext{
${ }^{93}$ See, e.g., John Dugard 'Diplomatic Protection' in James Crawford, Alain Pellet, Simon Olleson (eds) The Law of International Responsibility (OUP 2010) 1051, 1062-1063.

${ }^{94}$ Language used in Article 48(1)(b), ARSIWA (n 7).

95 Section 3(B)(iii).

${ }^{96}$ Rostam J Neuwirth and Alexandr Svetlicini, 'The current EU/US-Russia conflict over Ukraine and the WTO: a preliminary note on (trade) restrictive measures' (2016) 32:2 Post-Soviet Affairs 237, 248.

${ }^{97}$ Giergerch (n 5) para 10.

${ }^{98}$ Rebecca M Nelson, 'US Sanctions and Russia's Economy' Congressional Research Service (17 February 2017) 3 .

${ }^{99}$ Rostam J Neuwirth and Alexandr Svetlicini, 'The Economic Sanctions over the Ukraine Conflict and the WTO: "Catch-XXI" and the Revival of the Debate on the Security Exceptions' (2015) 49:5 Journal of World Trade 891, 894. See also Martin Dawidowicz, 'Third-party countermeasures: A progressive development of international law?' (2016) 29 QIL Zoom-in 3, 10 and Dawidowicz Third-Party Countermeasures in International Law (n 14) 235, albeit both in reference to the EU restrictive measures; Bothe (n 70) 35.
} 
without filing a complaint before the WTO's dispute settlement mechanism. ${ }^{100}$ If the sanctions do violate GATT, then there is the question of whether they would fall under the security exception enshrined under GATT Article XXI. ${ }^{101}$ The language of the provision is described as 'self-judging': a State can adopt measures it 'considers necessary for the protection of its essential security interests' ${ }^{102}$ As Lekhadia writes, the sanctioning countries could argue that Russia's annexation of Ukraine constitutes a 'threat to international peace and security' and therefore that the sanctions could fall under the scope of Article XXI. ${ }^{103}$ The US typically adopts sanctions in response to situations that are termed a threat to national security interests, which is consistent with the IEEPA; ${ }^{104}$ it remains to be seen however if the WTO dispute settlement body would accept a broad definition 'national interests'. Indeed, the exact purview of Article XXI would appear to be unclear as no opinion has been given on its scope. ${ }^{105}$ Similar issues arise with regard to GATS and TRIPS. ${ }^{106}$ Although the sanctions would be a violation of the latter treaties, to this writer's knowledge Russia has not issued a formal complaint and the US has not justified the measures under the treaties' respective security exceptions.

In addition, there are a series of bilateral US-Russia agreements in the areas of atomic energy and scientific and technical cooperation, which may be directly affected by the sectoral sanctions. This is notably the case of the 2013 Cooperation Agreement and the related 'Agreement for Cooperation in the field of peaceful uses of nuclear energy'.

Another illustration is the 2000 Agreement signed between Russia and the US on the 'Disposition of Plutonium Designated Plutonium no Longer Required for Defence Purposes, its Use and Cooperation in This Field' (PMDA), and the 2006 and 2010 protocols. The PMDA and its protocols were also suspended by Russia in October 2016. The suspensions were justified as a reciprocal measure taken by the Russian Federation in response to a fundamental change of circumstances caused by the US. ${ }^{107}$ Russia cited multiple reasons in justification of the suspension, which also included the American sanctions:

${ }^{100}$ Ibid 894-895; Nelson (n 98) 3. See also Ronzitti (n 8) 24, writing that Russia would have circulated a memo affirming the illegality of the EU and US sanctions; Mergen Doraev, "The "Memory Effect" of Economic Sanctions against Russia: Opposing Approaches to the Legality of Unilateral Sanctions Clash again' (2015) U. Pa. J. Int'1 L. 37:1 355, 412-413; Recall quoted texted at (n 24).

${ }^{101}$ See, e.g., Ronzitti (n 100) 22-24.

102 Neuwirth and Svetlicini (n 99) 905-906, quoting Article XXI(b).

${ }^{103}$ Rishika Lekhadia, 'Can the West Justify its Sanctions against Russia under the World Trade Law?' (2015) VII The Indian Journal of International Economic Law 151, 165-175.

104 IEEPA (n 71).

105 Neuwirth and Svetlicini (n 99) 906-907; Doraev (n 100) 378. The WTO did, however, discuss Article XXI in the unadopted Panel Report 'United States - Trade Measures affecting Nicaragua' (13 October 1986) L/6053. Further, Argentina sought an interpretation of Article XXI in 1982, which led to 'Decision Concerning Article XXI of the General Agreement of 30 November 1982' (2 December 1982) L/5426. For further information see 'Article XXI - Security Exceptions' in WTO Secretariat, GATT Analytical Index - Guide to GATT Law and Practice (2012), available online: < https://www.wto.org/english/res_e/booksp_e/gatt_ai_e/gatt_ai_e.htm>. Finally, it is possible that Saudi Arabia, the United Arab Emirates and Bahrain will raise the Security Exception in response to a complaint filed by Qatar on 31 July 2017 - 'Qatar files WTO complaints against the United Arab Emirates, Bahrain and Saudi Arabia’ (4 August 2017) < https://www.wto.org/english/news_e/news17_e/ds526_7_8rfc_04aug17_e.htm> - which would provide more insight on the interpretation of the GATT security exception.

${ }^{106}$ Neuwirth and Svetlicini (n 99) 893.

107 'Draft law suspending the Russia-US Plutonium Management and Disposition Agreement submitted to the State Duma' (3 October 2016) <http://en.kremlin.ru/acts/news/53009>, subsequently signed into law 'Law suspending Russian-US Plutonium Management and Disposition Agreement (PMDA) signed' (31 October 2016) $<$ http://en.kremlin.ru/acts/news/53167>. 
[T]he United States is taking measures to weaken the Russian economy and violate the rights of Russian citizens. Thus, in 2012 the United States passed the so-called Sergei Magnitsky law in accordance with which Washington openly sought to protect economic crime in the Russian Federation. In 2014 Washington passed a law supporting the freedom of Ukraine, which allows it to interfere in the domestic affairs of Russia. In addition, in 2014 the United States introduced sanctions against the Russian Federation, some of its territories, as well as companies and individuals.

The actions taken by the United States fundamentally changed the circumstances in which the Agreement and its protocols were signed. ${ }^{108}$

Though Russia appears to place the suspension under the framework of Article 62 VCLT 1969 , by invoking a 'fundamental change of circumstances' Russia could also be referring to the breaking down of communication and lack of partnership between the US and Russia; thus indicating that Russia no longer sees the benefit of upholding previous Agreements. In fact, when it suspended the agreements pertaining to nuclear energy, Russia seemed to be complaining about the interruption of American-Russian cooperation. The political climate at the time of both suspensions is significant: the beginning of October 2016 marked a period of high-tension between the US and Russia over Russia's alleged policies in Syria, to the extent that the Syria-talks were suspended. Within this context, the suspension of the PMDA was seen as 'a political gesture that is part of the deterioration of relations, particularly after the collapse of the Syrian cease-fire agreement. ${ }^{109}$ Also in October 2016, Russia terminated another agreement between Rosatom and the US department of Energy, referring to 'the notification received from the United States in 2014 regarding the termination of civil nuclear energy cooperation with Russia, as well as other hostile steps and statements by the United States'. ${ }^{110}$

The lack of US-Russia partnership is perceptible in Russia's countermeasure argument when it suspended the 2013 Cooperation Agreement. Russia claims that, as a result of the sanctions against it, the US is responsible for a 'substantial violation of the terms of the [2013] Agreement' and specifically Articles IV(3) and X(1) regarding US-Russia cooperation; the sanctions therefore directly 'affected the areas of cooperation under the Agreement'. ${ }^{111}$ In a comment by the Russian Ministry of Foreign Affairs, it is indicated that in 2014 the 'Americans effectively froze cooperation in science and technology in all areas

108 'Draft law suspending the Russia-US Plutonium Management and Disposition Agreement...' (n 107). See also Alexander Yakovenko, 'Why Russia was forced to suspend plutonium deal with US' RT (6 October 2016) <https://www.rt.com/op-edge/361794-russia-plutonium-nuclear-us-deal/> accessed 3 April 2014.

${ }^{109}$ Comment by Gary Samore in Michael R Gordon and Andrew E Kramer, 'Tension With Russia Rises as U.S. Halts Syria Negotiations' NY Times (3 $\quad$ October $\quad 2016)$ < https://www.nytimes.com/2016/10/04/world/middleeast/us-suspends-talks-with-russia-onsyria.html?rref=collection\%2Ftimestopic\%2FSyria>

110 'Comment by the Information and Press Department on the Russian Government's decision to terminate the 2010 Implementing Agreement between the Russian State Corporation for Atomic Energy (Rosatom) and the US Department of Energy (DOE) concerning cooperation on feasibility studies of the conversion of Russian research reactors to use low-enriched uranium fuel' (5 October 2016) <http://www.mid.ru/en/foreign_policy/news/-/asset_publisher/cKNonkJE02Bw/content/id/2489270>

111 'Decision to suspend the 2013 Cooperation Agreement' (n 27). 
specified in the Agreement and rendered impossible the implementation of projects'. ${ }^{112}$ In Russia's view, '[t]he regular extension of US sanctions against Russia, including the suspension of Russian-US nuclear energy cooperation'113 called for the adoption of countermeasures. ${ }^{114}$

It follows from the above that the US sectoral sanctions against Russia could violate obligations the former owes the latter and therefore constitute internationally wrongful acts. Provided these measures target the Russian State for alleged violations of obligations erga omnes committed against Ukraine, they could be justified as third-party countermeasures. ${ }^{115}$ We briefly address this issue in the ensuing sub-section. ${ }^{116}$

\section{(iii) Discussion on third-party countermeasures}

A question raised by this article multiple times but that is yet to be discussed is whether or not the wrongful US sanctions could be justified as third-party countermeasures.

The debate pertaining to such measures' legality has been a long one and was perhaps most salient during the drafting of the ARSIWA. ${ }^{117}$ Though ILC Special Rapporteur James Crawford believed that State practice demonstrated a growing trend that non-injured States can legally adopt countermeasures in response to violations of obligations erga omnes, ${ }^{118}$ he decided that the better view was to retain third-party countermeasures in ARSIWA in the form of a saving clause. ${ }^{119}$ Since then, scholars have argued that the ILC erred; they find that solidarity measures are a well-established means under customary international law to enforce obligations erga omnes. ${ }^{120}$ Further, in 2005, the Institut de Droit International (IDI) adopted the resolution on 'Obligations Erga Omnes in International Law', whereby in case of a 'grave breach of an erga omnes obligation' all States to whom the obligation was owed are entitled to adopt countermeasures. ${ }^{121}$ However, as suggested by Special Rapporteur Crawford, this

112 'Comment by the Information and Press Department on the Russian Government's directive suspending the 2013 Russian-US Agreement on Cooperation in Nuclear- and Energy-Related Scientific Research and Development' (5 October 2016) <http://www.mid.ru/en/foreign_policy/news//asset_publisher/cKNonkJE02Bw/content/id/2489260>

113 'Decision to suspend the 2013 Cooperation Agreement' (n 27).

114 On the issue regarding a lack of US-Russia partnership, see 'Assessment of Russian-US relations by Dimitri Medvedev' (19 January 2017) <http://government.ru/en/news/26148/>. According to this assessment, the US sanctions against Russia 'destroyed relations between the United States and Russia, which are at their lowest point in decades'.

115 However see Bothe (n 70) 36, arguing that if the GATT is considered to be a self-contained regime any violations of freedom of commerce could not be justified as a countermeasure.

${ }^{116}$ It goes without saying that the debate regarding third-party countermeasures deserves more attention than it is given here. For a more in-depth analysis see the references above at (n 14) and Focarelli (n 63); Linos-Alexander Sicilianos, Les réactions décentralisées à l'illicite: des contre-mesures à la légitime défense (Librairie générale de droit et de jurisprudence 1990) 135-177; Bederman (n 6).

117 For the discussion between ILC members on draft Article 54 see: Yearbook of the International Law Commission, vol I (2001), 34-57, meetings 2672 to 2674.

118 Third Report on State Responsibility by Special Rapporteur James Crawford (2000) UN Doc A/CN.4/507, 104, para. 395; Draft Article 54 [2000] in 'Draft articles provisionally adopted by the Drafting Committee on second reading' (21 August 2000) UN Doc A/CN.4/L.600*.

${ }^{119}$ Fourth Report on State Responsibility by Special Rapporteur James Crawford (2001) UN Doc A/CN.4/517, 18, para. 74. Yearbook of the International Law Commission, vol I (2001), 73, para. 47. James Crawford had already indicated the grey-areas surrounding third-party countermeasures in 'Third Report on State Responsibility...' (n 118), 104-105, para. 396.

${ }^{120}$ References above (n 14).

${ }^{121}$ IDI (Rapporteur Giorgio Gaja), 'Obligations Erga Omnes in International Law', Resolution adopted at the Krakow Session 2005, Article 5(c). 
could be linked to the fact that the IDI does not need to answer to States. ${ }^{122}$ Indeed, one of the reasons why third-party countermeasures were not codified in the final text is because of States' feedback.

During the drafting of the Articles, certain States expressed their desire for either the deletion of third-party countermeasures or their inclusion in the draft as a savings clause. ${ }^{123}$ Significantly, States who had previously adopted countermeasures against States responsible for violations erga omnes but who were not directly injured found that third-party countermeasures were insufficiently established in general international law. This was the case of the US, ${ }^{124}$ the United Kingdom ${ }^{125}$ and Tanzania. ${ }^{126}$ The reaction received from these States demonstrates the absence of opinio juris surrounding third-party countermeasures, ${ }^{127}$ which was another reason why Article 54 was included in ARSIWA as a saving clause ${ }^{128}$ and remains an issue even today. The present author is of the opinion that because the subjective element is lacking, it has not been sufficiently established that third-party countermeasures have been integrated within the international legal framework. A contrary view is, however, taken by Tams and Dawidowicz, who have both written that opinio juris can be inferred from State practice. ${ }^{129}$ It is argued here that this approach is inconsistent with the ICJ's jurisprudence ${ }^{130}$ and the method adopted by the ILC in the context of its conclusions on 'Identification of customary international law'. ${ }^{131}$ Notwithstanding the debate on how to

122 James Crawford, 'Responsibility for Breaches of Communitarian Norms: an Appraisal of Article 48 of the ILC Articles on Responsibility of States for Internationally Wrongful Acts' in Ulrich Fastenrath et al. (ed), From Bilateralism to Community Interest, essays in honour of Bruno Simma (OUP 2011) 224, 240.

${ }^{123}$ Summary of the 6th Committee debates, 55th meetings < http://www.un.org/law/cod/sixth/55/summary.htm>: 'Concern was also expressed over the concept of "collective countermeasures", which, as a tacit recognition of power politics in international relations, could lead to abuse. The taking of collective countermeasures by groups of States, on behalf of an injured State, outside the context of action by universal or regional international organizations, was opposed. Others urged limiting the right to take countermeasures to the State that was directly injured. It was further argued that the relationship between collective countermeasures and Chapter VII of the UN Charter was problematic; and that collective countermeasures raise the problem of the coordination between the States taking such measures.'

${ }^{124}$ UN Sixth Committee, Summary Record of the $18^{\text {th }}$ Meeting (4 December 2000) UN Doc A/C.6/55/SR.18, 13, para. 72 (US).

${ }^{125}$ UN Sixth Committee, Summary Record of the $14^{\text {th }}$ Meeting (10 November 2000) UN Doc A/C.6/55/SR.14, 7 pars 31-32 (United Kingdom)

${ }^{126}$ Ibid, 9, paras 45-49 (Tanzania). Tanzania expressed concern over the risk that countermeasures would be used by more powerful States against weaker States. See also Sicilianos, Les réactions décentralisées à l'illicite... (n 116) 172 to 173.

127 Recalling the ICJ's findings in North Sea Continental Shelf (Federal Republic of Germany/Denmark; Federal Republic of Germany/Netherlands) (Judgment) [1969] ICJ Report, para. 28. Denmark and the Netherlands had alleged that the Federal Republic of Germany's conduct amounted to acceptance of the equidistance method, yet it had not ratified the Geneva Convention of 1958. This element was of importance to the Court, which indicated that: ' $[I] f$ there had been a real intention to manifest acceptance or recognition of the applicability of the conventional régime - then it must be asked why it was that the Federal Republic did not take the obvious step of giving expression to this readiness by simply ratifying the Convention'.

128 Report of the International Law Commission on the work of its fifty-second session (2000) UN Doc A/55/10, 58, para. 356; Yearbook of the International Law Commission, vol I (2000) 303, para. 7 (Mr Crawford).

${ }^{129}$ Tams (n 14) 238-239; Martin Dawidowicz, 'Public Law Enforcement without Public Law Safeguards? An Analysis of State Practice on Third-Party Countermeasures and their relationship to the UN Security Council' (2006) BYBIL 333, 408 and 413. See Dawidowicz, Third-Party Countermeasures... (n 14) $250-255$ for additional arguments on opinio juris.

${ }^{130}$ See, e.g., North Sea Continental Shelf (n 127) para. 77, Colombian Peruvian asylum case (Colombia/Peru) (Judgment) [1950] ICJ Reports, 277. Military and Paramilitary Activities in and against Nicaragua (Nicaragua v. United States of America) (Merits, Judgment) [1986] ICJ Reports, paras 183-184 and para. 207.

${ }^{131}$ Fourth Report of the Special Rapporteur (8 March 2016) UN Doc A/CN.4/695, paras 3-5; Second Report of the Special Rapporteur (22 May 2014) UN Doc A/CN.4/672, para. 21. See also ILC, Identification of Customary 
assess the subjective element in customary international law, it is submitted that opinio juris is especially relevant in order to identify whether or not ambiguous State practice is recognized as law. ${ }^{132}$ This would apply to sanctions, which are primarily foreign policy tools. ${ }^{133}$ The debate is therefore methodological as it concerns a discussion on how State practice should be analysed and interpreted. ${ }^{134}$

Returning to the case at hand, according to Dawidowicz the sectoral sanctions against Russia are third-party countermeasures. He finds that these measures violate the sending States' obligations under the GATT and GATS. As they have not invoked the security exception as justification of these measures, they can be understood as third-party countermeasures. ${ }^{135}$ However, until Russia forces the way and makes claims before the WTO dispute body, the sanctioning entities may prefer to leave the question open. It is entirely possible that States prefer to avoid setting a precedent and would be reluctant to justify the measures legally. ${ }^{136}$ The absence of opinio juris may therefore be an indication that States adopting these measures prefer that collective sanctions remain an instrument of foreign policy and thus unregulated by international law. ${ }^{137}$ The same could be suggested for the security exception, in the sense that States may prefer to leave it undefined. Finally, States may even believe that their sanctions are acts of retorsion, and thus not an unlawful act that requires justification. ${ }^{138}$

That being said, if one were to take the view that third-party countermeasures are a valid circumstance precluding wrongfulness, the question is whether the wrongful US sanctions against Russia would fit within the category. This would depend on the erga omnes nature of the legal norms breached by Russia and the US' standing to enforce their observance. The fact that the identification of an obligation owed to the international community as a whole is 'mysterious' poses additional challenges, ${ }^{139}$ especially when faced with the complex realities

International Law, 'Text of the draft conclusions provisionally adopted by the Drafting Committee' (30 May 2016) UN Doc A/CN.4/L.872, Draft Conclusion 3, para. 4, point (2): 'Each element is to be separately ascertained. This requires an assessment of evidence for each element'.

${ }^{132}$ ILA, Final Report of the Committee on Formation of Customary (General) International Law, 'Statement of Principles Applicable to the Formation of General Customary International Law' (London Conference, 2000) 34-38; and Christian Dahlman, 'The Function of Opinio Juris in Customary International Law' (2012) 81 Nordic Journal of International Law 327, who argues opinio juris acts as a filter to prevent unwanted State practice from becoming part of customary international law.

133 The US government is very clear in stating that sanctions are an essential policy tool and an acceptable response to situations that are considered to constitute a national emergency. It is because of their foreign policy nature that US courts have a 'deferential' attitude towards sanctions.

${ }^{134}$ The present author thus argues that a so-called 'restrictive approach' should be adopted, see e.g. Olivier Corten, 'The Controversies Over the Customary Prohibition on the Use of Force: A Methodological Debate' (2005) 16:5 EJIL 803.

${ }^{135}$ Martin Dawidowicz, 'Third-party countermeasures: A progressive development of international law?' (2016) 29 QIL Zoom-in 3, 10. Dawidowicz, Third-party countermeasures... (n 14) 235.

${ }^{136}$ For example the EU guidelines on implementing and evaluating restrictive measures ambiguously reads: 'the restrictive measures should also respect the international obligations of the Union and its Member States, in particular the WTO Agreements'. In Council of the EU, Guidelines on implementation and evaluation of restrictive measures (sanctions) in the framework of the EU Common Foreign and Security Policy (15 June 2012) Doc Number ST 112052012 INIT, para. 11.

${ }^{137}$ Dahlman (n 132) 337-339, in particular 338-339: 'A state that behaves in a certain way, but does not want the behaviour to be generally practiced, does not express its approval of the practice as international law. It does not talk about its behaviour as exercising a legal right, since this would imply that every other state has an equal right to behave in the same way. If it needs to defend its behaviour, it usually says that an important national interest is at stake. When a behaviour is generally unwanted there is an absence of opinio juris.'

${ }^{138}$ Ruys (n 77) 32.

${ }^{139}$ Dawidowicz (n 14), quoting Brownlie, 271 footnote 208. 
of a fragmented international order. ${ }^{140}$ As explained above, the United States adopted sanctions against Russia for violating Ukraine's sovereignty and territorial integrity, undermining democratic principles and institutions in Ukraine, and contributing to the misappropriation of Ukraine's assets. There is certainly no doubt that the annexation of the territory of one State by another State constitutes aggression and therefore a violation of an obligation erga omnes. ${ }^{141}$ This is not necessarily the case regarding the sanctions adopted in response to behaviour undermining democratic processes and institutions in Ukraine and the misappropriation of Ukraine's assets. States have consented to multilateral and regional treaties demonstrating these norms' prominence in inter-State relations ${ }^{142}$ but this does not confirm their erga omnes nature. The very existence of a 'right' to democracy remains uncertain $^{143}$ and the adoption of sanctions against the misappropriation of states funds is recent practice. Though certain States have demonstrated their willingness to adopt sanctions in response to violations of these norms, they have also received pushback from other States. ${ }^{144}$ Consequently, their enforcement through unilateral coercive measures is subject to disagreement. ${ }^{145}$

\section{(iv) Conclusion}

To conclude on Executive Orders 13661 and 13662, the sanctions stemming from the former pose the issue of targeted sanctions under international law. In comparison to E.O. 13660, these measures list persons believed to be affiliated with the Russian State apparatus and constitute (in part) a response to a breach of an obligation erga omnes. They may therefore fall within the scope of State-to-State relations. On the other hand, the sanctions under E.O. 13662 more clearly target the Russian State by invoking its policies in Ukraine and targeting sectors of the State's economy. According to Russia, they would constitute a violation of GATT or bilateral agreements with the US. If the sanctions under either executive orders are believed to be unlawful, Russia could attempt to right a wrong by adopting countermeasures in order to induce the US to cease its wrongful behaviour. However, if the US were to argue that it adopted these sanctions in response to a breach of an obligation owed to the international community as a whole - in particular the prohibition of aggression - , one could reasonably qualify the sanctions as 'countermeasures adopted by a State other than the injured State' if is of the opinion that such measures are consistent with present-day international law. Under these circumstances, the wrongfulness of the US sanctions would be precluded and Russia would be barred from invoking the US State responsibility as it would be expected to comply with its secondary obligations of cessation and reparation.

\footnotetext{
${ }^{140}$ Martti Koskenniemi, 'Solidarity Measures State Responsibility as a New International Order?' (2002) 72 BYBIL 337, 347

${ }^{141}$ Barcelona Traction, Light and Power Company, Limited (Belgium v Spain) (Judgment) [1970] ICJ Reports, para. 34.

${ }^{142}$ For an overview see: Gregory Fox, 'Democracy, Right to, International Protection' and Kenneth Abbort, 'Corruption, fight against' both in Wolfrum (5).

${ }^{143}$ Fox (n 142); White and Abbas (n 15) 543; but see Thomas Franck, 'The Emerging Right to Democratic Governance' (1992) 86 AJIL 46-91.

${ }^{144}$ See further, Hofer (n 57) $30 \mathrm{ff}$.

145 The fact that Western States more frequently adopt unilateral coercive measures to uphold democratic principles and the rule of law suggests that only a certain group supports this practice. African and Latin American States show a tendency of responding to political crises through regional organizations, which are mandated to do so on the basis of their constitutional act. These states therefore appear to give precedence to multilateral sanctions.
} 


\section{Executive Order 13685}

Executive Order 13685 extends the asset freezes, travel bans and economic sanctions to persons and entities operating in Crimea. The sanctions do not seem to invoke Russia's State responsibility although they are a response to its perceived wrongful act. It is submitted that they fall within the scope of draft Article 41 of the ARSIWA.

Article 41(2) reads: 'No State shall recognize as lawful a situation created by a serious breach [...], nor render aid or assistance in maintaining that situation. ${ }^{146}$ This provision is to be read in conjunction with Article 40, defining a serious breach as a gross and systematic violation of a peremptory norm of general international law. The Executive Order of 19 December can be understood as a refusal to recognize the consequence of Russia's annexation of Crimea by prohibiting financial and trade relations with the region. ${ }^{147}$ Inasmuch as Russia's annexation of Crimea was a breach of the prohibition of aggression, which continues to the present day, it could ostensibly qualify as a serious breach. By prohibiting business-relations with the region, the US is withholding from lending support to Russia's wrongful act and attempting to bring an end to the violation in conformity with Article 41(1): 'States shall cooperate to bring to an end through lawful means any serious breach within the meaning of article 40'. Hence, in order to be consistent with Article 41, the executive order needs to constitute a 'lawful means'. Given their similarity with the other three executive orders, their legality could pose similar issues with regard to procedural rights, investment agreements, obligations under GATT and GATS, and bilateral agreements between the US and Crimean entities. If the measures against the Crimean region are considered unlawful, there are numerous obstacles for Russia to invoke US responsibility and adopt countermeasures. Indeed, even though Russia considers Crimea to have integrated its territory, third States do not acknowledge this as to do so would be to recognize an internationally wrongful act. Therefore, unless the targeted persons are Russian, only Ukraine could exercise diplomatic protection. This is highly unlikely as Kiev is in favour of the Western sanctions ${ }^{148}$ and therefore would appear to have consented to the sanctions.

\section{Conclusion}

As seen from the sections above, there is no clear-cut answer as to the US sanctions' legality as each measure needs to be evaluated and appreciated separately. The different Executive

\footnotetext{
${ }^{146}$ See also the ICJ's finding in Legal Consequences of the Construction of a Wall in the Occupied Palestinian Territory (Advisory Opinion) [2004] ICJ Reports, para. 159.

147 The Russian MFA seems to have reached opposite interpretation: 'The approval of additional unilateral US and EU sanctions against the Republic of Crimea and the City of Sevastopol is direct evidence of the West's recognition of the fact that the Crimeans' decision to reunite with Russia was unanimous and free. This explains the "collective" nature of sanctions against them.' in 'Comment by the Information and Press Department of the Russian Foreign Ministry on the latest US and EU sanctions against Crimea and Sevastopol' (20 December 2014) <http://www.mid.ru/en/foreign_policy/news/-/asset_publisher/cKNonkJE02Bw/content/id/856045> However, see 'The United States and Canada still cannot accept the results of the free expression of public will held in Sevastopol and Crimea in March 2014' quoted from 'Comment by Foreign Ministry Spokesman Alexander Lukashevich on the latest US and Canadian sanctions against Russia' (20 December 2014) <http://www.mid.ru/en/foreign_policy/news/-/asset_publisher/cKNonkJE02Bw/content/id/856021>

148 'Ukrainian PM: Maintain Western Sanctions Until Russian Withdrawal' RadioFreeEurope/ RadioLiberty (16 July 2016) https://www.rferl.org/a/ukraine-hroysman-maintain-western-sanctions-russia/27803562.html; 'Ukraine's Poroshenko says sanctions on Russia must stay' Reuters (19 April 2017) https://www.reuters.com/article/us-ukraine-president-sanctions/ukraines-poroshenko-says-sanctions-on-russiamust-stay-idUSKBN17L0Z5
} 
Orders fall under different legal categories depending on what type of measure is adopted, on whose responsibility is invoked and the reasons for the listing.

Turning to the question that gave rise to this article - Russia's standing to invoke the countermeasure argument against the US - it would seem that Russia would have little ground to adopt countermeasures in response to potential violations stemming from E.O. 13685. With regard to the targeted sanctions under Executive Orders 13660 and 13661, Russia could invoke US responsibility provided, where necessary, the conditions of diplomatic protection are fulfilled. The question then is whether the US could invoke the countermeasure argument should the sanctions be unlawful. It is argued here that as E.O. 13660 targets non-State actors for their individual behaviour, the US would be barred from invoking the countermeasure argument. Therefore, Russia could adopt countermeasures against the US for its wrongful sanctions against Russian persons under E.O. 13660. On the other hand, the measures adopted under E.O. 13661 target non-State actors while invoking Russia's responsibility for its unlawful behaviour in Ukraine. In other words, the Russian State is targeted through nonState actors that are believed to be, one way or another, responsible for or to have contributed to the wrongful act. The targeted sanctions under E.O. 13661 could therefore be placed within the scope of State-to-State relations, enabling the US to invoke the countermeasure argument should their legality be challenged by Russia. However, the sanctions would fall under the third-party countermeasure category, provided such measures are considered permissible. This means that the reason for their adoption would have to be a violation of an obligation owed to the international community as a whole or to an interested group of States. Though the violation of Ukraine's territorial and sovereign integrity constitutes a breach of an obligation erga omnes the misappropriation of Ukrainian State funds and the destabilization of Ukraine's democratic processes and institutions are more difficult to interpret in this manner.

Finally, E.O. 13662 is more straightforward as these sanctions clearly target the Russian State and sectors of its economy. Any potential violation would arise from bilateral and multilateral agreements both Russia and the US are party to, or from customary international law. If the sanctions adopted under E.O. 13662 would be unlawful, Russia could invoke the US responsibility, and the latter could attempt to preclude their wrongfulness by raising the third-party countermeasure argument, bringing us back to the findings on E.O. 13661.

\section{Non-UN Sanctions in the Wonderland where Law meets Policy}

Discussions on the legal nature of the US sanctions adopted in response to Russia's involvement in the Ukrainian crisis lead to questions pertaining to the consequences of (unlawful) targeted sanctions - such as who can invoke US responsibility and whether such measures can be justified as lawful countermeasures - and the permissibility of third-party countermeasures should the US sanctions constitute violations of obligations owed to Russia under GATT, GATS or bilateral treaties between the two States.

The US sanctions against Russia are an illustration of a broader trend that has become commonplace, especially amongst 'developed' States. There is no shortage of unilateral sanctions regimes adopted by the US, the European Union and aligning countries, Canada, Australia, etc. against non-State actors or States as a means to enforce international law or community values. When sanctions are adopted to enforce international law they indubitably fall within the framework of decentralized enforcement. However, when they are adopted in 
defence of norms that do not necessarily constitute obligations erga omnes, such as democratic principles and the prohibition of corruption, their place within the international legal system becomes less straightforward. In so far as they respect the obligations the sending State owes to the target, they constitute retorsions and there is little reason to question their legality. However, as this paper demonstrates, wrongful sanctions that do not fit within the framework of countermeasures challenge the classical understanding of unilateral coercive measures. Measures adopted against non-State actors for their private conduct fall outside the scope of State-to-State responsibility, and thus outside the original conception of sanctions in the international legal framework. ${ }^{149}$ Whereas sanctions are traditionally understood as a means of enforcement, from a policy perspective sanctions' can be adopted to, inter alia, constrain the targets' activities or signal disapproval. When policy-makers adopt sanctions for purposes other than enforcement, the resulting measures will not automatically fit within the legal categories devised for unilateral coercive measures. This is perhaps most clearly illustrated by E.O. 13660, which could be understood as a signal to Russia not interfere any further in the Ukrainian crisis. Consequently there is a discrepancy between the use of sanctions as a foreign policy tool and how they are conceived in the international legal order. This discrepancy perhaps explains why unilateral sanctions do not automatically fit within the framework devised by doctrine and jurisprudence.

Moreover Russia's reaction to the US sanctions brings to mind numerous states' objections to unilateral coercive measures. Though the US may believe that it is its responsibility to use its economic power to promote international norms and that it is acting within its rights when it adopts sanctions to protect its national and foreign policy interests, a majority of countries resent the fact that the US uses its economic power to impose, not only certain type of norms, but also its own interpretation of these norms. Their objections to such practice are demonstrated by the frequent adoption of UNGA resolutions condemning the adoption of unilateral coercive measures. ${ }^{150}$ After voting in favour of Resolution 70/185 (2015) on 'Unilateral economic measures as a means of political and economic coercion against developing countries', the Russian Federation stated that it 'firmly and consistently opposed the introduction of unilateral economic measures against developing countries' and 'noted with regret that the unilateral application of such measures had not decreased, despite the fact that every year, the General Assembly condemned the practice'. ${ }^{151}$ In addition to its claims that non-UN sanctions 'are contrary to international law', Russia is highly critical of these measures' unilateral nature and especially of US unilateralism. If States view unilateral sanctions as illegitimate this could have repercussions on sanctions' effectiveness as a means to enforce international law. The target would be more likely to develop policies of noncompliance and resistance, which would include developing arguments that a certain practice is illegal. The consequence would be the broadening of international disputes, as is clearly the case between the US and the Russian Federation.

It follows that if international law wants to have an impact on State practice and provide for effective enforcement, it is necessary to find a way to bridge not only the gap between legal theory and political practice but also between States that accept the frequent adoption of unilateral coercive measures and those that contest this practice.

\footnotetext{
149 White (n 21) 158-159.

${ }^{150}$ Discussed in Hofer (n 57).

${ }^{151}$ Verbatim Record of UNGA $2^{\text {nd }}$ Committee (12 November 2015) A/C.2/70/SR.31, paras 24-25 (Russia).
} 